\title{
Asam Salisilat sebagai Penginduksi Ketahanan Tanaman Padi terhadap Penyakit Hawar Daun Bakteri
}

\section{Salicylic Acid as Inducers for Rice Resistance Against Bacterial Leaf Blight Disease}

\author{
Christoffol Leiwakabessy, Meity Suradji Sinaga, Kikin Hamzah Mutaqin, \\ Trikoesoemaningtyas, Giyanto* \\ Institut Pertanian Bogor, Bogor 1660
}

\begin{abstract}
ABSTRAK
Penggunaan asam salisilat sebagai penginduksi ketahanan beberapa jenis tanaman saat ini mulai mendapat banyak perhatian. Asam salisilat diyakini berperan penting dalam menginduksi ketahanan tanaman terhadap patogen. Penelitian ini bertujuan menentukan peran dan keefektifan asam salisilat sebagai penginduksi ketahanan tanaman padi (Oryza sativa) terhadap penyakit hawar daun bakteri yang disebabkan oleh Xanthomonas oryzae pv. oryzae. Percobaan disusun dalam rancangan acak lengkap faktorial yang terdiri atas 3 faktor (varietas, asam salisilat, dan patotipe), tiap perlakuan diulang 3 kali. Hasil penelitian menunjukkan bahwa asam salisilat mampu memperpanjang periode laten $X$. oryzae pv. oryzae patotipe IV dan VIII pada padi varietas Conde dan Ciherang, dapat menginduksi ketahanan varietas padi, dan mampu menekan laju infeksi kedua patotipe bakteri tersebut. Asam salisilat juga mampu menginduksi ketahanan padi varietas Conde dan Ciherang dalam menekan area di bawah kurva perkembangan penyakit (AUDPC) X. oryzae pv. oryzae patotipe IV dan VIII.
\end{abstract}

Kata kunci: AUDPC, Oryaza sativa, patotipe, Xanthomonas oryzae pv. oryzae

\begin{abstract}
The use of salicylic acid as resistance inducers agents in several plants species was well known. Salicylic acid has been believed to play an important role in inducing resistance against some pathogen. This research was aimed to study the role and effectiveness of salicylic acid as inducers for the resistance of some rice variety against bacterial leaf blight caused by Xanthomonas oryzae pv. oryzae. The experiment was arranged in completely randomized factorial design with three factors i.e. rice variety, salicylic acid, and pathotypes, each treatment was replicated three times. The results showed that salicylic acid could prolong the latent period of $X$. oryzae pv. oryzae pathotypes IV and VIII in paddy rice varieties Conde and Ciherang, induce the resistance of rice varieties as well as reducing the rate of infection of the two mentioned pathotypes. Salicylic acid was also able to induce the resistance of Conde and Ciherang varieties in order to suppress area under disease progress curve (AUDPC) of $X$. oryzae pv. oryzae pathotypes IV and VIII.
\end{abstract}

Key words: AUDPC, Oryaza sativa, pathotypes, Xanthomonas oryzae pv. oryzae

*Alamat penulis korespondensi: Departemen Proteksi Tanaman, Fakultas Pertanian Institut Pertanian Bogor, Jalan Kamper, Kampus Darmaga IPB, Bogor 16680

Tel: 0251-8629364, Faks: 0251-8629362, surel: giyanto2@yahoo.com 


\section{PENDAHULUAN}

Penyakit hawar daun bakteri (HDB) merupakan salah satu penyakit penting pada pertanaman padi. Penyakit HDB yang disebabkan oleh bakteri patogen $X$. oryzae pv. oryzae menjadi salah satu penyebab kehilangan hasil di negara-negara penghasil padi khususnya di Asia (Ezuka dan Kaku 2000). Berbagai upaya pengendalian penyakit ini telah dilakukan baik secara biotik (Putra dan Giyanto 2014; Krishanti et al. 2015) maupun secara abiotik (Mustafa et al. 2013; Kim et al. 2015), tetapi hingga saat ini penyakit HDB masih menjadi kendala utama produksi padi di daerah tropis maupun subtropis. Berdasarkan hasil survei Sudir dan Yuliani (2016) pada 10 provinsi di Indonesia ditemukan 3 patotipe yang dominan, yaitu patotipe III $(30 \%)$, IV (36\%), dan VIII (34\%).

Asam salisilat adalah salah satu agens penginduksi ketahanan yang dilaporkan dapat digunakan untuk pengendalian patogen tanaman. Menurut Hayat et al. (2010), asam salisilat merupakan senyawa fenol sederhana yang berperan penting dalam mengatur proses fisiologi dan respons imunisasi tanaman. Pemanfaatan asam salisilat sebagai sinyal transduksi dalam jaringan pertahanan tanaman telah diamati dan dikarakterisasi pada sejumlah gen yang berfungsi dalam biosintesis asam salisilat. Rangkaian dari proses ini meliputi konjugasi, akumulasi, dan crosstalk hormon tanaman seperti asam jasmonat, etilen, asam absisi, auksin, giberrelin, sitokinin, dan brassinosteroid (An dan Mou 2011).

Menurut Mohan-Babu et al. (2003), induksi ketahanan tanaman padi terhadap penyakit HDB dengan konsentrasi asam salisilat 1000 $\mu$ mol menyebabkan peningkatan kandungan senyawa fenol sehingga dapat menekan perkembangan penyakit HDB. Kombinasi perlakuan asam salisilat dan sodium nitroprusside dapat meningkatkan pigmen fotosintesis dan aktivitas beberapa enzim pertahanan tanaman pada tanaman kacang tanah yang terinfeksi Peanut mottle virus (Kobeasy et al. 2011). Mandal et al. (2009) melaporkan bahwa aplikasi asam alisilat
$200 \mu \mathrm{M}$ pada daun dan akar dapat menekan perkembangan penyakit layu Fusarium (Fusarium oxysporum f.sp.lycopersicum) pada tanaman tomat dan terjadi peningkatan enzim fenilalaninamonia liase dan peroksidase. Asam salisilat secara eksogen dapat memengaruhi pertumbuhan tanaman, fotosintesis, hubungan air dan tanaman, dan aktivitas beberapa jenis enzim yang berperan terhadap cekaman biotik dan abiotik (Zamaninejad et al. 2013). Berdasarkan hal tersebut maka penelitian ini bertujuan memperoleh konsentrasi asam salisilat yang optimum sebagai penginduksi ketahanan padi varietas IR64, Ciherang, dan Conde terhadap $X$. oryzae pv. oryzae patotipe IV dan VIII.

\section{BAHAN DAN METODE}

\section{Persiapan Tanam dan Xanthomonas oryzae pv. oryzae}

Tiga varietas benih padi (IR64, Ciherang, dan Conde) koleksi BB Padi Sukamandi didesinfeksi dengan natrium hipoklorit selama 2 menit dan dibilas 3 kali dengan air steril. Benih padi dikeringanginkan dan disterilisasi dengan metode hot water treatment pada suhu $55^{\circ} \mathrm{C}$ selama 20 menit. Selanjutnya benih padi direndam dalam air steril selama 24 jam dan disemai pada wadah plastik berisi medium campuran tanah dan pupuk kandang $(1: 1, b / b)$. Setelah berumur 14 hari, bibit padi dipindahkan ke pot plastik berdiameter $30 \mathrm{~cm} \times 40 \mathrm{~cm}$.

Inokulum $X$. oryzae pv. oryzae patotipe IV dan VIII (koleksi BB Padi Sukamandi) diperbanyak pada medium Wakimoto (OEPP 2007) dan diamati pertumbuhannya selama 72 jam, selanjutnya disimpan pada medium agaragar miring sebelum digunakan untuk pengujian patogenisitas. Patotipe IV dan VIII digunakan dalam penelitian ini karena lebih dominan dibandingkan dengan patotipe III. Konsentrasi $X$. oryzae pv. oryzae yang digunakan untuk pengujian patogenisitas ialah $10^{7} \mathrm{cfu} \mathrm{mL}^{-1}$. Uji patogenisitas bakteri $X$. oryzae pv. oryzae dilakukan pada padi varietas IR64 berumur 30 hari untuk memastikan bahwa galur ini benarbenar $X$. oryzae pv oryzae patotipe IV dan VIII. 


\section{Rancangan Penelitian}

Penelitian disusun dalam rancangan acak lengkap faktorial dengan tiga faktor, yaitu asam salisilat $(\mathrm{A}, \mathrm{A} 0=0, \mathrm{~A} 1=5, \mathrm{~A} 2=10$, $\mathrm{A} 3=15 \mathrm{mM}$ ); patotipe $X$. oryzae pv. oryzae (B, B0=kontrol, B1=Patotipe Xoo IV, B2= Patotipe Xoo VIII; dan varietas padi (C, $\mathrm{C} 1=\mathrm{IR} 64, \mathrm{C} 2=$ Ciherang, C3=Conde). Setiap perlakuan diulang tiga kali. Setiap satuan percobaan diambil 4 sampel tanaman untuk diamati perkembangan penyakit HDB.

Aplikasi Asam Salisilat dan Inokulasi Xanthomonas oryzae pv. oryzae

Penentuan konsentrasi asam salisilat $\left(\mathrm{HOC}_{9} \mathrm{H}_{8} \mathrm{COOH}\right.$, Merck KGaA cas No. 6672-7) mengacu pada hasil uji pendahuluan dengan berbagai konsentrasi asam salisilat (SA) $(0,5,10,15$, dan $20 \mathrm{mM})$. Asam salisilat disiapkan dengan melarutkan dalam alkohol $70 \%$ dan dibuat larutan stok sebanyak $200 \mathrm{~mL}$ untuk setiap perlakuan uji. Asam salisilat disemprotkan pada tanaman padi berumur 40 hari setelah tanam(HST) dengan konsentrasi 5, 10, $15 \mathrm{mM}$ sebanyak $20 \mathrm{~mL}$ per tanaman.

Inokulasi $X$. oryzae pv. oryzae (patotipe IV dan VIII) dilakukan pada tanaman padi berumur 43 HST dengan konsentrasi $10^{7} \mathrm{cfu} \mathrm{mL}^{-1}$ menggunakan metode clipping, yaitu memotong ujung daun, tempat ujung ini dicelupkan ke dalam suspensi $X$. oryzae pv. oryzae (Ou 1985). Tanaman yang telah diinokulasi disungkup dengan plastik transparan selama 3-4 hari supaya kelembapan tetap tersedia bagi patogen.

\section{Pengamatan}

Pengamatan penyakit dilakukan terhadap periode laten, laju infeksi (Van der Planck 1963), dan area di bawah kurva perkembangan penyakit (AUDPC) (Madden et al. 2007). Pengamatan ini dilakukan dengan menggunakan kriteria skor kerusakan untuk menghitung keparahan penyakit HDB, yaitu $0,0<\mathrm{x} \leq 1 \%$ daun terserang HDB; $1,1<\mathrm{x} \leq$ $5 \%$ daun terserang $\mathrm{HDB} ; 2,5<\mathrm{x} \leq 15 \%$ daun terserang $\mathrm{HDB} ; 3,15<\mathrm{x} \leq 25 \%$ daun terserang HDB; 4, $25<\mathrm{x} \leq 50 \%$ daun terserang HDB; dan $5,>50 \%$ daun terserang HDB (modifikasi
SES IRRI, 2014). Pengamatan penyakit dilakukan dengan interval waktu 5 hari.

\section{Analisis Aktivitas Enzim-Enzim yang Terlibat dalam Pertahanan Tanaman}

Analisis aktivitas enzim-enzim pertahanan tanaman mencakup peroksidase (Hammerschmidt et al. 1982), polifenoloksidase (Malick dan Singh 1980), dan $\beta-1-3$ glukanase (Pan et al. 1991) dilakukan sebelum dan setelah inokulasi X. oryzae pv. oryzae. Data hasil pengamatan dianalisis menggunakan perangkat lunak Microsoft Excel 2013 dan SAS versi 9.2. Apabila terdapat perbedaan nyata dilanjutkan dengan uji Duncan pada $\alpha$ $5 \%$ dan $1 \%$.

\section{HASIL}

\section{Patogenisitas $X$. oryzae pv. oryzae}

Hasil uji patogenisitas $X$. oryzae pv. oryzae patotipe IV dan VIII terhadap varietas IR64 menunjukkan rata-rata gejala penyakit HDB mulai muncul pada hari ke-5 sampai ke-8 disertai perubahan warna daun dari hijau menjadi keabu-abuan. Patotipe IV lebih dominan dibandingkan dengan patotipe VIII pada padi varietas IR64. Hal ini menunjukkan bahwa dengan periode laten yang lebih singkat patotipe IV lebih cepat berkembang pada jaringan tanaman daripada patotipe VIII.

\section{Penyakit HDB pada Varietas Padi yang Diinokulasi dengan Dua Patotipe Xanthomonas oryzae pv. oryzae dan Pemberian Asam Salisilat}

Analisis ragam menunjukkan bahwa asam salisilat mampu menekan perkembangan penyakit HDB dan memperpanjang periode laten patogen ini pada varietas padi. Hal ini diketahui dari nilai AUDPC yang rendah. Asam salisilat mampu meningkatkan induksi ketahanan varietas padi untuk menekan laju infeksi penyakit HDB dan memperpanjang periode laten varietas padi, tetapi tidak dapat menekan AUDPC. Asam salisilat mampu memengaruhi induksi ketahanan varietas padi dalam menekan laju infeksi dan AUDPC patotipe $X$. oryzae pv. oryzae, tetapi tidak 
berpengaruh nyata terhadap periode laten. Pengaruh asam salisilat, patotipe, dan varietas tidak berbeda nyata terhadap AUDPC (Tabel 1).

Periode laten pada padi varietas Conde tanpa asam salisilat lebih panjang dan laju infeksinya lebih rendah, sedangkan pemberian asam salisilat dengan konsentrasi 10 dan 15 $\mathrm{mM}$ tanpa inokulasi patogen memiliki laju infeksi yang tinggi, dan periode laten panjang. Periode laten yang lebih panjang dan laju infeksi yang lebih rendah ditunjukkan oleh pemberian asam salisilat $10 \mathrm{mM}$ pada ketiga varietas dibandingkan dengan tanpa pemberian asam salisilat dengan konsentrasi 5 dan $15 \mathrm{mM}$ setelah diinokulasi dengan $X$. oryzae pv. oryzae patotipe IV dan VIII (Tabel 2).

Perlakuan asam salisilat $10 \mathrm{mM}$ pada padi varietas IR64 mampu menekan AUDPC patotipe IV dan VIII, tetapi tidak berbeda dengan perlakuan IR64-SA0. Nilai AUDPC pada perlakuan IR64-SA10 diperoleh lebih rendah dibandingkan dengan perlakuan IR64SA5 dan IR64-SA15, tetapi tidak berbeda dengan IR64-SA0 dan IR64-SA15 pada patotipe yang sama. Perlakuan IR64-SA10 terhadap patotipe IV diperoleh AUDPC lebih rendah dibandingkan dengan perlakuan Conde-SA5 dan Conde-SA15. Perlakuan yang sama tidak berbeda nyata dengan CiherangSA0, Ciherang-SA5, Ciherang-SA10, dan Ciherang-SA15, serta Conde-SA0 dan CondeSA10 (Tabel 3).

Nilai AUDPC perlakuan SA10 pada padi varietas Ciherang terhadap patotipe IV tidak berbeda nyata dengan perlakuan CiherangSA0, Ciherang-SA5, dan Ciherang-SA15, tetapi berbeda nyata dengan Ciherang-SA15 terhadap patotipe VIII. Perlakuan yang sama juga tidak berbeda nyata terhadap perlakuan IR64-SA10 dan IR64-SA5 dalam menekan patotipe VIII serta IR64-SA0 terhadap patotipe IV (Tabel 3).

Perlakuan tanpa asam salisilat (SA0) pada padi varietas Conde menunjukkan nilai AUDPC berbeda nyata dibandingkan dengan perlakuan Conde-SA15, Conde-SA10, dan

Tabel 1 Analisis ragam pengaruh aplikasi asam salisilat dan patotipe Xanthomonas oryzae pv. oryzae pada varietas padi terhadap periode laten, laju infeksi, dan AUDPC

\begin{tabular}{lccccccc}
\hline Pengamatan & SA & Pato & Var & SA x Pato & SA x Var & Pato x Var & SA x Pato x Var \\
\hline Periode laten & $0.00^{* *}$ & $0.00^{* *}$ & $0.00^{* *}$ & $0.00^{* *}$ & $0.00^{* *}$ & $0.19^{\text {th }}$ & $0.42^{\text {tn }}$ \\
Laju infeksi & $0.00^{* *}$ & $0.02^{*}$ & $0.00^{* *}$ & $0.08^{\text {tn }}$ & $0.00^{* *}$ & $0.00^{* *}$ & $0.11^{\text {tn }}$ \\
AUDPC & $0.00^{* *}$ & $0.00^{* *}$ & $0.11^{\text {tn }}$ & $0.00^{* *}$ & 0.86 tn & $0.02^{*}$ & $0.39^{\text {tn }}$ \\
\hline
\end{tabular}

**, berbeda sangat nyata pada $\alpha 1 \%$; , berbeda nyata pada $\alpha 5 \%$; ${ }^{\text {tn }}$, tidak berbeda nyata.

SA, asam salisilat; Pato, patotipe; Var, varietas.

Tabel 2 Pengaruh asam salisilat dalam menginduksi ketahanan varietas padi terhadap Xanthomonas oryzae pv. oryzae patotipe IV dan VIII berdasarkan periode laten (PL) dan laju infeksi (LI)

\begin{tabular}{|c|c|c|c|c|c|c|}
\hline \multirow{2}{*}{ Perlakuan } & \multicolumn{2}{|c|}{ Kontrol } & \multicolumn{2}{|c|}{ Patotipe IV } & \multicolumn{2}{|c|}{ Patotipe VIII } \\
\hline & PL & LI & PL & LI & PL & LI \\
\hline Conde + SA0 & $11.00 \mathrm{a}$ & 0.72 & $8.00 \mathrm{abc}$ & 0.47 & $10.67 \mathrm{a}$ & 0.37 \\
\hline Conde + SA5 & $8.67 \mathrm{bc}$ & 0.69 & $7.67 \mathrm{bc}$ & 0.21 & $7.00 \mathrm{bc}$ & 0.89 \\
\hline Conde + SA10 & $11.33 \mathrm{a}$ & 0.50 & $9.67 \mathrm{a}$ & 0.62 & $10.67 \mathrm{a}$ & 0.21 \\
\hline Conde + SA15 & $9.67 \mathrm{ab}$ & 0.67 & $7.00 \mathrm{cde}$ & 0.29 & $7.00 \mathrm{bc}$ & 0.21 \\
\hline Ciherang + SA0 & $5.67 \mathrm{e}$ & 0.87 & $5.33 \mathrm{e}$ & 0.29 & $5.67 \mathrm{c}$ & 0.85 \\
\hline Ciherang + SA5 & 7.33 cde & 0.23 & $6.67 \mathrm{cde}$ & 0.59 & $6.33 \mathrm{bc}$ & 0.40 \\
\hline Ciherang + SA10 & $8.33 \mathrm{bc}$ & 0.88 & $8.00 \mathrm{abc}$ & 0.36 & $8.67 \mathrm{ab}$ & 0.20 \\
\hline Ciherang + SA15 & $8.33 \mathrm{bc}$ & 0.96 & $7.33 \mathrm{bcd}$ & 0.50 & $7.00 \mathrm{bc}$ & 0.55 \\
\hline IR64 + SA0 & $6.00 \mathrm{de}$ & 0.77 & $5.67 \mathrm{de}$ & 0.23 & $5.67 \mathrm{c}$ & 0.20 \\
\hline IR64 + SA5 & 7.00 cde & 0.82 & $6.33 \mathrm{cde}$ & 0.39 & $6.67 \mathrm{bc}$ & 0.54 \\
\hline IR64 + SA10 & $8.67 \mathrm{bc}$ & 0.84 & $9.00 \mathrm{ab}$ & 0.65 & $8.00 \mathrm{abc}$ & 0.54 \\
\hline IR64 + SA15 & $8.00 \mathrm{bcd}$ & 0.95 & $7.00 \mathrm{cde}$ & 0.46 & $7.00 \mathrm{bc}$ & 0.53 \\
\hline
\end{tabular}

Angka yang diikuti oleh huruf yang sama pada kolom yang sama tidak berbeda nyata menurut uji DMRT pada $\alpha$ 5\% 
Conde-SA5 dalam menekan patotipe IV dan VIII, tetapi tidak berbeda dengan CiherangSA10 patotipe VIII. Demikian pula perlakuan Conde-SA10 mampu menekan patotipe IV, tetapi tidak berbeda terhadap perlakuan Ciherang-SA10 patotipe IV maupun VIII. Nilai AUDPC terendah diamati pada perlakuan Conde-SA0 patotipe IV dan Ciherang-SA10 patotipe VIII (Tabel 3).

\section{Pengaruh Asam Salisilat terhadap Aktivitas Enzim-Enzim Pertahanan Tanaman}

Pengaruh asam salisilat terhadap aktivitas enzim-enzim pertahanan tanaman menunjukkan bahwa aktivitas enzim peroksidase mengalami peningkatan setelah inokulasi pada perlakuan SA10-PatVIIIIR64 (A2B2C1) dan SA10-PatVIII-Conde (A2B2C3). Selanjutnya aktivitas enzim

Tabel 3 Pengaruh asam salisilat dalam menginduksi ketahanan varietas padi terhadap $X$. oryzae pv. oryzae patotipe IV dan VIII berdasarkan AUDPC

\begin{tabular}{lr}
\hline Perlakuan & \multicolumn{1}{c}{ AUDPC* } \\
\hline IR64-SA0-PatIV & $316.67 \mathrm{n}$ \\
IR64-SA0-PatVIII & $1950.00 \mathrm{a}$ \\
IR64-SA5-PatIV & $1406.67 \mathrm{~d}$ \\
IR64-SA5-PatVIII & $383.27 \mathrm{~m}$ \\
IR64-SA10-PatIV & $415.00 \mathrm{l}$ \\
IR64-SA10-PatVIII & $983.33 \mathrm{f}$ \\
IR64-SA15-PatIV & $923.33 \mathrm{~g}$ \\
IR64-SA15-PatVIII & $1906.67 \mathrm{~b}$ \\
Ciherang-SA0-PatIV & $226.67 \mathrm{o}$ \\
Ciherang-SA0-PatVIII & $200.00 \mathrm{o}$ \\
Ciherang-SA5-PatIV & $398.33 \mathrm{~lm}$ \\
Ciherang-SA5-PatVIII & $698.33 \mathrm{j}$ \\
Ciherang-SA10-PatIV & $46.67 \mathrm{r}$ \\
Ciherang-SA10-PatVIII & $26.67 \mathrm{rs}$ \\
Ciherang-SA15-PatIV & $568.33 \mathrm{k}$ \\
Ciherang-SA15-PatVIII & $1076.67 \mathrm{e}$ \\
Conde-SA0-PatIV & $15.20 \mathrm{~s}$ \\
Conde-SA0-PatVIII & $750.00 \mathrm{i}$ \\
Conde-SA5-PatIV & $778.33 \mathrm{~h}$ \\
Conde-SA5-PatVIII & $146.67 \mathrm{p}$ \\
Conde-SA10-PatIV & $45.07 \mathrm{r}$ \\
Conde-SA10-PatVIII & $73.33 \mathrm{q}$ \\
Conde-SA15-PatIV & $920.00 \mathrm{~g}$ \\
Conde-SA15-PatVIII & $1558.33 \mathrm{c}$ \\
\hline Angka yang diikuti oleh huruf yang sama pada kolom \\
tidak berbeda nyata menurut uji DMRT pada $\alpha$ 5\% \\
*, nilainya dikurangi dengan kontrol \\
\hline
\end{tabular}

polifenoloksidase setelah inokulasi diperoleh nilai tertinggi pada perlakuan SA10-PatVIIICiherang (A2B2C2) dan SA10-PatVIIIConde (A2B2C3), tetapi perlakuan A2B2C3 tidak mengalami peningkatan enzim ini. Aktivitas enzim $\beta$-1,3-glukanase mengalami peningkatan setelah inokulasi pada semua perlakuan dibandingkan dengan sebelum inokulasi. Aktivitas tertinggi dari enzim ini diamati pada perlakuan SA10-PatVIIICiherang (A2B2C2) dan SA10-PatVIIIConde (A2B2C3) diikuti dengan perlakuan SA5-PatIV-Ciherang (A1B1C2) (Tabel 4).

\section{PEMBAHASAN}

Perkembangan keparahan penyakit ditentukan oleh virulensi patogen, ketahanan tanaman dan lingkungan yang saling mendukung perkembangan patogen. Hasil penelitian menunjukkan bahwa padi varietas Conde dan Ciherang mempunyai laju infeksi dan AUDPC yang lebih rendah dibandingkan dengan padivarietas IR64. Semakin rendahnilai laju infeksi dan AUDPC akan memicu induksi ketahanan tanaman padi terhadap $X$. oryzae pv. oryzae patotipe IV dan VIII. Laju infeksi yang rendah akan memperpanjang periode laten penyakit HDB pada kedua varietas. Padi varietas Conde diketahui memiliki gen tahan $\mathrm{Xa} 7$ yang mampu mengatasi serangan penyakit HDB dibandingkan dengan kedua varietas lainnya. Tasliah (2012) melaporkan bahwa varietas Conde memiliki gen ketahanan $X a 7$ yang tahan terhadap $X$. oryzae pv. oryzae. Ketahanan padi varietas Ciherang tergolong moderat, namun dapat ditingkatkan status ketahanannya menjadi tahan dibandingkan dengan varietas IR64. Hal ini kemungkinan disebabkan oleh pengaruh dari asam salisilat dan genotipe tanaman yang memengaruhi tingkat induksi ketahanan varietas ini terhadap patotipe IV dan VIII. IR64 tergolong varietas rentan dan tidak dapat ditingkatkan ketahanannya setelah diinduksi dengan asam salisilat.

Aplikasi SA10 mM sangat efektif dalam menekan laju infeksi HDB dibandingkan dengan tanpa asam salisilat. 
Tabel 4 Aktivitas enzim pertahanan tanaman (unit $\mu \mathrm{g}^{-1}$ ) pada tiga varietas padi yang terinduksi ketahanannya oleh asam salisilat sebelum dan setelah inokulasi $X$. oryzae pv. oryzae

\begin{tabular}{cccccccc}
\hline \multirow{2}{*}{ Perlakuan } & \multicolumn{3}{c}{ Sebelum inokulasi } & & \multicolumn{3}{c}{ Sesudah inokulasi } \\
\cline { 2 - 3 } \cline { 6 - 7 } & Peroksidase & Polifenoksidase & $\begin{array}{c}\beta-1.3- \\
\text { glukanase }\end{array}$ & & Peroksidase & Polifenoksidase & $\begin{array}{c}\beta-1.3- \\
\text { glukanase }\end{array}$ \\
\hline A0B1C1 & 0.000 & 0.000 & 0.002 & & 0.000 & 0.003 & 0.337 \\
A1B1C1 & 0.000 & 0.013 & 0.002 & & 0.000 & 0.007 & 0.323 \\
A2B2C1 & 0.000 & 0.000 & 0.003 & & 0.020 & 0.023 & 0.328 \\
A3B1C1 & 0.000 & 0.003 & 0.003 & & 0.000 & 0.013 & 0.326 \\
A0B1C2 & 0.020 & 0.023 & 0.003 & & 0.000 & 0.023 & 0.335 \\
A1B1C2 & 0.016 & 0.007 & 0.003 & & 0.000 & 0.013 & 0.417 \\
A2B2C2 & 0.000 & 0.027 & 0.003 & & 0.000 & 0.027 & 0.470 \\
A3B1C2 & 0.000 & 0.007 & 0.003 & & 0.000 & 0.013 & 0.362 \\
A0B1C3 & 0.000 & 0.027 & 0.004 & & 0.000 & 0.017 & 0.023 \\
A1B1C3 & 0.000 & 0.007 & 0.003 & & 0.000 & 0.023 & 0.055 \\
A2B2C3 & 0.000 & 0.002 & 0.003 & & 0.018 & 0.027 & 0.467 \\
A3B2C3 & 0.000 & 0.000 & 0.003 & & 0.000 & 0.000 & 0.330 \\
\hline A & 0.000 &
\end{tabular}

$\mathrm{A}$ (asam salisilat: $\mathrm{A} 0=0, \mathrm{~A} 1=5, \mathrm{~A} 2=10, \mathrm{~A} 3=15 \mathrm{mM}$ ), B (patotipe $X$. oryzae, pv. oryzae: $\mathrm{B} 0=\mathrm{kontrol}, \mathrm{B} 1=$ patotipe $\mathrm{IV}, \mathrm{B} 2=$ patotipe $\mathrm{VIII}), \mathrm{C} 1$ (varietas: $\mathrm{C} 1=\mathrm{IR} 64, \mathrm{C} 2=$ Ciherang, $\mathrm{C} 3=$ Conde).

Hal ini menunjukkan bahwa secara endogen kandungan asam salisilat pada tanaman padi cukup tinggi daripada tanaman lainnya sehingga jika konsentrasi ditingkatkan maka akan terjadi peningkatan reaksi kerentanan tanaman ini terhadap penyakit HDB. Secara endogen kandungan asam salisilat pada tanaman padi 10 kali lebih tinggi daripada tanaman lainnya, yaitu sebanyak 30-40 $\mu \mathrm{g}$ per tanaman (Silverman et al. 1995; Vicente dan Plasencia 2011). Ibrahim (2012) juga menyatakan bahwa aplikasi asam salisilat $10 \mathrm{mM}$ pada tanaman wortel dapat menekan Xanthomonas vesicatoria.

Setiap patogen, demikian juga dengan $X$. oryzae pv. oryzae membutuhkan energi yang cukup dalam proses infeksi dan kolonisasi. Pada saat awal proses infeksi, energi yang tersedia tidak cukup bagi patogen tersebut sehingga membutuhkan waktu yang panjang untuk melakukan proses infeksi ke tanaman. Keragaman respons antarpatotipe kemungkinan disebabkan oleh pengaruh dari genotipe tanaman dan patogen $X$. oryzae pv. oryzae dalam memberikan respons terhadap penyakit HDB. Dalam patosistem penyakit HDB interaksi antara tanaman inang dan patogen bersifat dinamis dan memiliki kesamaan dengan teori gen for gen ketika gejala penyakit terjadi akibat adanya interaksi inkompatibel antara genavirulen dan gen resisten dari patogen dan tanaman (Nayak 2008).

Saat $X$. oryzae pv. oryzae menginfeksi tanaman diduga akan mengubah keseimbangan hormon asam salisilat sehingga memicu pengaktifan senyawa-senyawa pertahanan tanaman. Saat patogen menyerang tanaman terjadi manipulasi terhadap hormon tanaman yang dapat berdampak positif maupun negatif baik melalui peningkatan ketahanan tanaman maupun pengaruhnya terhadap pertumbuhan tanaman seperti kekerdilan, jantan mandul, dan penurunan produksi (Holeski et al. 2012). Selanjutnya Ankenbauer dan Cox (1988) menyatakan bahwa beberapa genus Xanthomonas dapat menyintesis asam salisilat selain berperan dalam ketahanan tanaman terhadap infeksi patogen, juga dapat memediasi tanaman terhadap cekaman abiotik.

Hasil penelitian menunjukkan terdapat peningkatan aktivitas enzim pertahanan tanaman pada perlakuan asam salisilat. Dari ketiga enzim yang dianalisis, enzim peroksidase merupakan enzim yang kurang terlihat aktivitasnya baik sebelum dan setelah inokulasi dibandingkan kedua enzim yang lainnya. Pemberian asam salisilat $10 \mathrm{mM}$ 
setelah inokulasi mampu meningkatkan aktivitas enzim peroksidase pada varietas Conde. Kedua jenis enzim yang lain seperti polifenoloksidase dan $\beta$-1,3-glukanase aktivitasnya lebih terlihat. Resistensi varietas kentang berkorelasi dengan aktivitas enzim polifenoloksidase, PAL, asam klorogenat, dan fenol yang berperan penting dalam menghambat infeksi penyakit busuk lunak pada kentang (Pectobacterium atrosepticum, P. carotovorum subsp. brasiliensis, dan Dickeya spp.) (Ngadze et al. 2012). Asam salisilat memengaruhi aktivitas enzim-enzim antioksidan seperti hidrogen peroksida yang bekerja sebagai second messenger dalam mengatur respons pertahanan tanaman (Harfouche et al. 2008).

Hasil penelitian membuktikan bahwa asam salisilat berperan penting dalam meningkatkan induksi ketahanan tanaman padi terhadap patotipe $X$. oryzae pv. oryzae. Agens penginduksi asam salisilat berpotensi untuk dikembangkan dalam pengendalian penyakit HDB.

Perlindungan tanaman terhadap patogen melalui teknologi induksi ketahanan dapat dilakukan secara eksogen. Induksi ketahanan tanaman dapat digunakan sebagai agens penginduksi kimia atau biologi yang menjadi komponen penting dalam program pengelolaan penyakit tanaman.

Perlakuan konsentrasi SA10 mM secara tunggal terbukti efektif dapat menginduksi ketahanan varietas Conde dan Ciherang untuk menekan $X$. oryzae pv. oryzae patotipe IV dan VIII. Perlakuan asam salisilat mampu meningkatkan aktivitas enzim peroksidase dan polifenoloksidase pada varietas IR64 dan Conde serta $\beta$-1,3-glukanase pada ketiga varietas. Mekanisme aplikasi asam salisilat dalam menekan $X$. oryzae pv. oryzae masih perlu dikaji lebih dalam pada ekosistem padi yang berbeda.

\section{UCAPAN TERIMA KASIH}

Penulis mengucapkan terima kasih kepada Badan Litbang Pertanian, Kementerian Departemen Pertanian yang telah mendanai sebagian kegiatan penelitian ini melalui program KKP3N dengan No. kontrak: 691/ LB.620/I.1/2/2013.

\section{DAFTAR PUSTAKA}

An C, Mou Z. 2011. Salicylic Acid and its function in plant immunity. J Integrative PlantBiol.53(6):412-428.DOI:https://doi. org/10.1111/j.1744-7909.2011.01043.x.

Ankenbauer RG, Cox CD. 1988. Isolation and characterization of Pseudomonas aeruginos $a$ mutants requiring salicylic acid for pyochelin biosynthesis. J Bacteriol. 170:5364-5367. DOI: https://doi. org/10.1128/jb.170.11.5364-5367.1988.

Ezuka A, Kaku H 2000. A historical review of bacterial blight of rice. Bull Nat Inst Agrobiol Res. 15(2000):1-207.

Hammerschmidt R, Nuckles M, Kuc J. 1982. Association of enhanced peroxidase activity with induced systemic resistance of cucumber to Colletotrichum lagenarium. Physiol Plant Pathol. 20:7382. DOI: https://doi.org/10.1016/00484059(82)90025-X.

Harfouche A, Rugini E, Mencarelli F, Botondi R, Muleo R. 2008. Salicylic acid induces $\mathrm{H} 2 \mathrm{O} 2$ production and endochitinase gene expression but not ethylene biosynthesis in Castanea sativa in vitro model system. J Plant Physiol. 165:734-744. DOI: https:// doi.org/10.1016/j.jplph.2007.03.010.

Hayat Q, Hayat S, Irfan M, Ahmad A. 2010. Effect of exogenous salicylic acid under changing environment: a review. Environ Exp Bot. 68(1):14-25. DOI: https://doi.org/10.1016/j. envexpbot.2009.08.0055.

Holeski L, Jander G, Agrawal A. 2012. Transgenerational defense induction and epigenetic inheritance in plants. Trends Ecol Evol. 27:618-626. DOI: https://doi. org/10.1016/j.tree.2012.07.011.

Ibrahim YE. 2012. Activities of antioxidants enzymes in salicylic acid treated tomato against Xanthomonas vesicatoria. Afr $\mathrm{J}$ Microbiol Res. 6(27):5678-5682. 
[IRRI] International Rice Research Institute. 2014. Standard evaluation system for rice. Manila (PH): IRRI.

Kim SI, Song JT, Jeong JY, Seo HS. 2015. Niclosamide inhibits leaf blight caused by Xanthomonas oryzae in rice. Nature. 6:21209. DOI: https://doi.org/10.1038/ srep21209.

Krishanti NPRA, Wahyudi AT, Nawangsih AA. 2015. Non-pathogenic phyllosphere bacteria producing bioactive compounds as biological control of Xanthomonas oryzae pv oryzae. Int J Pharma Bio Sci. 6(1):801-810.

Kobeasy MI, El-Beltagi HS, El-Shazly MA, Khattab EAH. 2011. Induction of resistance in Arachis hypogaea L. against Peanut mottle virus by nitric oxide and salicylic acid. Physiol Mol Plant Pathol. 76(2):112118. DOI: https://doi.org/10.1016/j. pmpp.2011.07.005.

Mandal S, Mallick N, Mitra A. 2009. Salicylic acid-induced resistance to Fusarium oxysporum f. sp. lycopersici in tomato. Plant Physiol Biochem. 47(7):642649. DOI: ttps://doi.org/10.1016/j. plaphy.2009.03.001.

Madden L, Hughes G, van den Bosch F. 2007. The Study of Plant Disease Epidemics. St. Paul (US): APS Press.

Malick C, Singh M. 1980. Phenolics. Plant enzymology. Histo Enzymol. 190:286.

Mohan-Babu R, Saajena A, Samundeesar V, Sreedhar A, Vidhyasekeran P, Reddy MS. 2003. Induction of bacterial blight (Xanthomonas oryzae pv. oryzae) resistance in rice by treatment with acibenzolar-S-methyl. Ann Appl Biol. 143(2003):333-340. DOI: https://doi. org/10.1111/j.1744-7348.2003.tb00302.x.

Mustafa A, Saleem IY, Mahmood S, Hannan A, Akhtar M. 2013. Field evaluation of new fungicides against rice (Oryza sativa) diseases. Pak J Phytopathol. 25(02):141145.

Nayak D, Bose LK, Singh UD, Singh S, Nayak P. 2008. Measurement of genetic diversity of virulence in populations of
Xanthomonas oryzae pv. oryzae in India. Comm Biomet Crop Sci. 3(1):16-28.

Ngadze E, Icishahayo D, Coutinho T, van der Waals J. 2012. Role of polyphenol oxidase, peroxidase, phenylalanine ammonia lyase, chlorogenic acid, and total soluble phenols in resistance of potatoes to soft rot. Plant Dis. 96:186-192. DOI: https://doi. org/10.1094/PDIS-02-11-0149.

Ou SH. 1985. Rice Disease $2^{\text {nd }}$ edition. London (UK): CMI. Hlm 30.

OEPP/EPPO 2007. Xanthomonas oryzae. 37(3): 543-553. DOI: https://doi. org/10.1111/j.1365-2338.2007.01162.x.

Pan S, Ye X, Kuc J. 1991. Association of $\beta$-1,3glucanase activity and isoform pattern with systemic resistance to blue mold in tobacco induced by stem injection with Peronospora tabacina or leaf inoculation with tobacco mosaic virus. Physiol Mol Plant Pathol. 39(1):25-39. DOI: https:// doi.org/10.1016/0885-5765(91)90029-H.

Putra C, Giyanto. 2014. Kompatibilitas Bacillus spp. dan aktinomiset sebagai agens hayati Xanthomonas oryzae pv. oryzae dan pemacu pertumbuhan Padi. J Fitopatol Indones. 10(5):160-169. DOI: https://doi.org/10.14692/jfi.10.5.160.

Silverman, PM, Seskar D, Kanter P, Schweizer JP, Mètraux I, Raskin I. 1995. Salicylic acid in rice biosynthesis, conjugation and possible role. Plant Physiol. 108: 633-639. DOI: https://doi.org/10.1104/ pp.108.2.633.

Sudir, Yuliani D. 2016. Composition and distribution of Xanthomonas oryzae pv. oryzae pathotypes, the pathogen of rice bacterial leaf blight in Indonesia. Agrivita. 38(2):174-185. DOI: https://doi. org/10.17503/agrivita.v38i2.588.

Tasliah. 2012. Gen ketahanan tanaman padi terhadap bakteri hawar daun (Xanthomonas oryzae pv. oryzae). J Litbang Pertanian. 31(3):103-112.

Van der Planck J. 1963. Plant Diseases: Epidemics and Control. New York (US): Academic Press. 
Vicente R, Plasencia J. 2011. Salicylic acid beyond defence: its role in plant growth and development. J Exp Bot. 62(10):33213338. DOI: https://doi.org/10.1093/jxb/ err031.

Zamaninejad M, Khorasani S, Moeini M, Heidarian A. 2013. Effect of salicylic acid on morphological characteristics, yield and yield components of corn (Zea mays L.) under drought condition. Eur J Exp Biol. 3(2):153-161. 